\title{
STUDI KOMPARASI MODEL PEMBELAJARAN KOOPERATIF TIPE TEAM ASSISTED INDIVIDUALIZATION DAN TIPE NUMBERED HEADS TOGETHER TERHADAP HASIL BELAJAR KIMIA PADA TOPIK STRUKTUR ATOM
}

\author{
I G A Gita Permata Dewi, ${ }^{1}$, I Nyoman Selamat, ${ }^{2}$, I Nyoman Suardana ${ }^{3}$ \\ 1,2,3 Universitas Pendidikan Ganesha
}

A R T I C L E I N F O Article history:

Received 19 April 2018

Received in revised form

6 October 2018

Accepted 12 October 2018

Available online 20 October 2018

Kata Kunci:

hasil belajar kimia,

Numbered Heads Together,

Team Assisted

Individualization

\begin{abstract}
A B S T R A K
Penelitian ini bertujuan membandingkan hasil belajar kimia antara siswa yang dibelajarkan dengan model pembelajaran kooperatif tipe TAI dan tipe NHT. Jenis penelitian ini termasuk penelitian semu (quasi exsperiment) dengan rancangan penelitian pre-test post-test nonequivlent control group design. Pupulasi penelitian ini adalah siswa kelas X SMA Negeri 1 Sidemen yang berjumlah 178 siswa. Sampel ditentukan secara cluster random sampling dan diperoleh siswa kelas X3 sebagai kelas Eksperimen 1 yang dibelajarkan dengan model pembelajaran kooperatif tipe TAI, sedangkan siswa kelas X2 sebagai kelas Eksperimen 2 yang dibelajarkan dengan model pembelajaran kooperatif tipe NHT. Data hasil belajar siswa dikumpulkan dengan menggunakan tes pilihan ganda dan esai. Data hasil belajar siswa dianalisis secara deskriptif dan inferensial dengan menggunakan independent sample t-test, dengan taraf signifikasi 5\%. Hasil penelitian menunjukkan terdapat perbedaan hasil belajar kimia antara siswa yang dibelajarkan dengan menggunakan model pembelajaran kooperatif tipe TAI dan tipe NHT, dari hasil penelitian didapatkan rata-rata skor hasil belajar siswa yang dibelajarkan dengan model pembelajaran kooperatif tipe TAI sebesar 75,54 dan tipe NHT sebesar 80,03.
\end{abstract}

\section{Pendahuluan}

Kimia merupakan salah satu bagian dari ilmu pengetahuan alam. Ilmu kimia merupakan ilmu yang mempelajari tentang materi dan perubahan materi serta energi yang menyertainya (Chang, 2005). Johnstone (2006), hakikat ilmu kimia pada dasarnya terdiri atas tiga aspek, yaitu makroskospis, submikroskospis, dan simbol. Aspek makroskopis adalah aspek yang menjadi bagian dari kejadian yang dialami oleh siswa dalam kehidupan sehari-hari. Aspek submikroskopis adalah kajian partikulat mengenai atom, ion, molekul, struktur dan sekaligus merupakan kajian secara konseptual dibalik fenomena makroskopis tersebut. Aspek simbol adalah aspek yang berfungsi untuk mengomunikasikan ilmu kimia, seperti notasi atau persamaan reaksi, model dan grafik. Ketiga aspek ini memberikan kontribusi terhadap kualitas pemahaman siswa saat menjelaskan suatu fenomena yang ditemui pada saat mempelajari ilmu kimia.

Secara umum, hasil belajar kimia terutama pada materi struktur atom masih rendah, hal ini disebabkan karena rendahnya pemahaman siswa pada konsep-konsep kimia sehingga sering menyebabkan terjadinya miskonsepsi pada siswa, hal ini sesuai dengan penelitian yang dilakukan oleh Solahuddin (2002), rendahnya pemahaman konsep kimia dikarenakan materi struktur atom yang bersifat abstrak. Banyaknya siswa yang mengalami miskonsepsi pada materi struktur atom akan berdampak pada hasil belajar yang rendah.

SMA Negeri 1 Sidemen merupakan salah satu sekolah yang memiliki nilai rata-rata ulangan harian di bawah KKM (kriteria ketuntasan minimum) pada materi struktur atom. Sebagai contoh, rata-rata hasil belajar kimia pada ulangan harian kelas X1, X2, X3, X4, dan X5 yaitu 71,50, 66,24, 72,56, 68,41, dan 70,3.

\footnotetext{
1 Corresponding author.

E-mail : igustilanangputrab@yahoo.co.id (I G A Gita Permata Dewi),
} 
Dari rata-rata tersebut didapat bahwa hasil belajar kimia siswa kelas X masih tergolong rendah, dengan nilai ketuntasan minimal, yaitu 75 .

Permasalahan yang sering terjadi dalam pembelajaran kimia adalah rendahnya hasil belajar kimia siswa. Salah satu penyebab rendahnya hasil belajar kimia adalah penggunaan model pelajaran yang kurang tepat dalam proses belajar mengajar, pembelajaran kimia tidak hanya diperlukan keaktifan dari guru tetapi juga keaktifan siswa sehingga terjadi kesinambungan dalam proses belajar mengajar. Salah satu model pembelajaran yang dapat lebih mengaktifkan siswa dalam proses pembelajaran adalah model pembelajaran kooperatif. Pembelajaran kooperatif merupakan bentuk pembelajaran dengan cara siswa belajar dan bekerja dalam kelompok-kelompok kecil secara kolaboratif yang anggotanya terdiri dari empat sampai lima orang dengan struktur kelompok yang heterogen (Rusman, 2012).

Terdapat beberapa tipe model pembelajaran kooperatif seperti, STAD (student team achievmen division), TGT (team games tournament), Jigsaw, TAI (team assisted individualization), NHT (Numbered heads together) dan GI (group investigation) (Sutirman, 2013). Model pembelajaran kooperatif tipe TAI merupakan model pembelajaran kooperatif yang menggabungkan belajar individu dengan belajar kelompok. Kelompok terdiri dari 4-5 orang dengan anggota kelompok yang heterogen. Pada model pembelajaran ini sebelum siswa belajar kelompok, siswa belajar terlebih dahulu secara individu (Slavin, 2008).

Dalam setiap tipe model pembelajaran berpengaruh terhadap hasil belajar yang diperoleh siswa. Sarwendah, dkk. (2013) melakukan penelitian terhadap pengaruh model pembelajaran TGT dan TAI, diperoleh bahwa model pembelajaran TAI lebih baik dibandingkan dengan TGT hal ini dapat dilihat dari rata-rata hasil belajar siswa sebesar 74,9 untuk TGT dan 77,8 untuk TAI pada materi pokok sistem koloid. Setiap model pembelajaran memiliki kekurangan dan kelebihan. TAI memiliki keunggulan seperti: 1) meningkatkan hasil belajar, 2) meningkatkan motivasi belajar pada siswa, 3) mengurangi perilaku yang mengganggu dan konflik antar kelompok, dan 4) membantu siswa yang lemah dalam pembelajaran. Kelemahan dari TAI adalah menimbulkan rasa kompetitif, sikap diskriminasi, dan timbul rasa egois (Slavin, 2008).

Model pembelajaran kooperatif yang lainnya yaitu NHT. Pada tipe ini masing-masing siswa dalam setiap kelompok memiliki nomor dan hanya satu siswa yang akan dipanggil untuk mewakili kelompoknya. Diskusi yang dilakukan adalah usaha siswa untuk membagi informasi sehingga setiap siswa mengetahui jawaban dari permasalahan yang ditugaskan guru (Slavin, 2008). Ciri khas dari tipe ini adalah hanya menginginkan satu siswa yang mewakili kelompknya tapi tanpa menginformasikan sebelumnya kepada kelompok tersebut siapa yang akan menjadi wakilnya.

Keunggulan model pembelajaran kooperatif tipe NHT, yaitu (1) meningkatkan hasil belajar, (2) memperdalam pemahaman siswa, (3) meningkatkan motivasi siswa dalam pembelajaran, (4) mengembangkan rasa percaya diri siswa, (5) dapat mengembangkan rasa saling memiliki. Kelemahan model pembelajaran kooperatif tipe ini adalah memungkinkan terjadinya pengulangan pemanggilan nomor dan tidak semua anggota kelompok dipanggil oleh guru (Slavin, 2008).

Pengaruh model pembelajaran kooperatif tipe NHT dapat dilihat dari hasil penelitian Mulyana (2016) diperoleh bahwa model pembelajaran kooperatif tipe NHT dapat meningkatkan hasil belajar siswa pada materi kemampuan alam dan sosial budaya. Marhadi (2014) melakukan penelitian terhadap penerapan model pembelajaran kooperatif tipe NHT, hasil yang diperoleh yaitu model pembelajaran kooperatif tipe NHT dapat meningkatkan hasil belajar siswa.

Model pembelajaran kooperatif tipe TAI dan tipe NHT merupakan model pembelajaran yang menekankan pada struktur-struktur khusus yang dirancang untuk memengaruhi pola-pola interaksi anatar siswa. Melalui model pembelajaran kooperatif tipe TAI dan NHT diharapkan mampu mengubah proses pembelajaran yang awalnya berpusat pada guru (teacher center) menjadi berpusat pada siswa (student center). Selain itu dengan meningkatnya aktivitas siswa diharapkan siswa lebih mudah dalam mempelajarai konsep kimia sehingga dapat meningkatkan hasil belajar.

Perbedaan kedua model pembelajaran ini, yaitu pada model pembelajaran kooperatif tipe NHT langsung dilakukan diskusi kelompok, sedangkn pada model pembelajaran kooperatif tipe TAI didahului dengan mengerjakan permasalahan secara individu terlebih dahulu kemudian mendiskusikan permasalahan yang ada dengan anggota kelompoknya.

Berdasarkan paparan tersebut, penulis tertarik untuk melakukan penelitiaan mengenai komparasi hasil belajar kimia pada topik struktur atom anatara model pembelajaran kooperatif tipe TAI dan kooperatif tipe NHT. Model pembelajaran ini diharapkan dapat menjadi refrensi dalam penggunaan model pembelajaran yang tepat untuk meningkatkan hasil belajar siswa. 


\section{Metode}

Penelitian ini merupakan eksperimen semu (quasi eksperimen) dengan rancangan pre-test post-tes nonequivalent control group design. Penelitian ini menggunakan dua kelas yang dipilih secara cluster random sampling. Kelas pertama dipilih sebagai kelas eksperimen 2 dan kelas kedua dipilih sebagai kelas eksperimen 1. Populasi penelitian ini adalah siswa kelas X SMA Negeri 1 Sidemen. Pada saat pemilihan sampel terpilih siswa kelas X2 dan X3. Sampel dalam penelitian ini terdiri dari dua kelas, yaitu kelas eksperimen 1 dan kelas eksperimen 2. Dalam penetuannya, dilakukan dengan cara mengundi dua kelas tersebut sehingga didapatkan X2 sebagai kelas eksperimen 2 dan X3 sebagai kelas eksperimen 1. Pada kelas eksperimen 1 dibelajarkan dengan menggunakan model pembelajaran kooperatif tipe TAI dan pada kelas eksperimen 2 dibelajarkan dengaan menggunakan model pembelajaran kooperatif tipe NHT.

Prosedur dalam penelitian ini terdiri dari tahap persiapan, tahap pelaksanaan, dan tahap analisis data. Pengumpulan data hasil belajar siswa dilakukan dengan memberikan tes hasil belajar pre-test dan post-test. Untuk mengukur hasil belajar dalam penelitian ini, digunakan instrument berupa tes objektif dan essay, LKS, RPP, serta rubrik aktifitas dan respon siswa. Instrument dalam penelitian ini terdiri dari 25 soal objektif dan 6 soal essay. Sebelum digunakan, instrument divalidasi oleh 2 orang dosen, kemudian instrument dilakukan uji coba untuk mengetahui validitas isi, daya pembeda, tingkat kesukaran, dan reliabilitas.

Hipotesis dalam penelitian ini diuji dengan menggunakan uji analisis t-test. Sebelum dilakukan uji hipotesis, nilai pre-test dan post-test dilakukan uji normalitas, homogenitas, linieritas, homogenitas kemiringan garis regresi, dan uji kesetaraan kelompok

\section{Hasil dan pembahasan}

Hasil penelitian terdiri dari grafik deskripsi hasil belajar pada kelompok TAI dan kelompok NHT. Grafik deskripsi hasil belajar siswa dapat dilihat pada Gambar 1

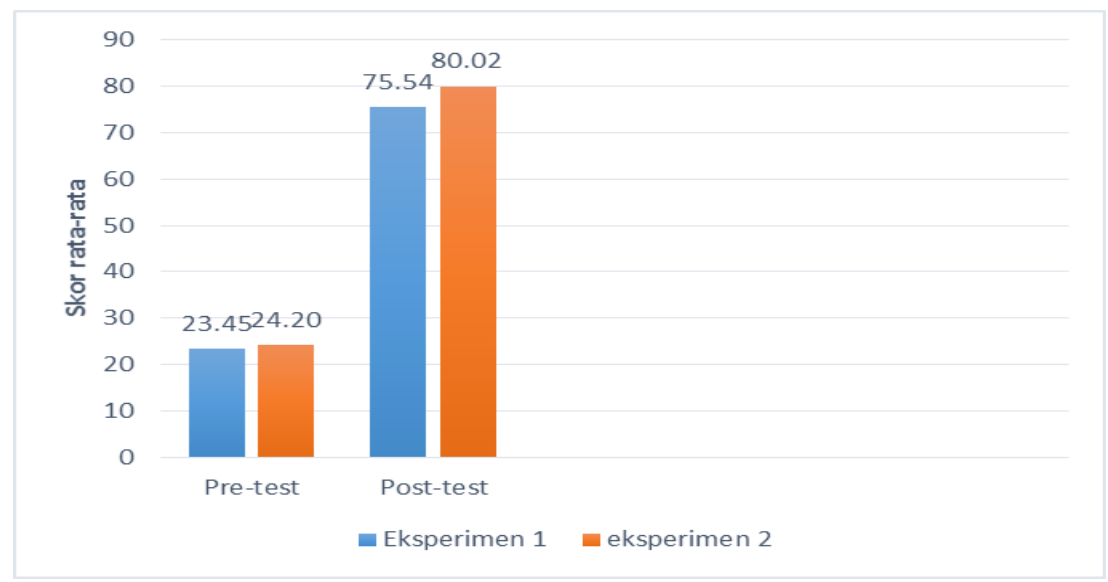

Gambar 1. Grafik Deskripsi Hasil Belajar

Rekapitulasi aktivitas dan respon siswa dapat dilihat pada tabel 1 dan tabel 2.

Tabel 1. Rekapitulasi Aktivitas Siswa pada Kelas Eksperimen 1 dan Kelas Eksperimen 2

\begin{tabular}{ccccccc}
\hline & \multicolumn{2}{c}{ Rata-rata } & \multicolumn{2}{c}{ Kategori } \\
Aspek & Eks. 1 & Eks. 2 & Mi & SD & Eks. 1 & Eks. 2 \\
\hline Mengajukan pertanyaan & 2,59 & 2,75 & 2,5 & 0.5 & Cukup Aktif & Aktif \\
Menjawab pertanyaan & 2,68 & 2,70 & 2,5 & 0,5 & Cukup Aktif & Cukup Aktif \\
Antusiasme & 2,61 & 2,68 & 2,5 & 0,5 & Cukup Aktif & Cukup Aktif \\
\hline
\end{tabular}

Tabel 2. Ringkasan Data Respon Siswa pada Tiap Aspek Penskoran pada Model Pembelajaran Kooperatif Tipe TAI dan NHT 


\begin{tabular}{cccccc}
\hline No Aspek & $\begin{array}{c}\text { Rata-rata } \\
\text { Skor } \\
\text { Eksperimen 1 }\end{array}$ & $\begin{array}{c}\text { Kriteria } \\
\text { Rata-rata } \\
\text { Skor }\end{array}$ & Kriteria \\
& Motivasi & 3,79 & Positif & 3,94 & Sksperimen 2 \\
\hline 1 & Interaksi & 3,72 & Positif & 3,90 & Sangat Positif \\
2 & Tanggung jawab & 3,79 & Positif & 3,82 & Positif \\
3 & Pengetahuan & 3,69 & Positif & 3,73 & Positif \\
4 & Rata-rata & 3,75 & Positif & 3,85 & Positif \\
\hline
\end{tabular}

\section{Uji Asumsi}

Pada penelitian eksperimen akan dilakukan uji hipotesis menggunakan uji t-test. Sebelum dilakukan uji $t$-test dilakukan uji asumsi, yaitu uji normalitas, uji homogenitas, uji linieritas, dan uji kemiringan garis regresi. Uji normalitas data dilakukan dengan menggunakan statistik Kolmogrov-Smirnov dan Shapiro-Wilk terhadap nilai pre-test dan post-test dari kelompok TAI dan kelompok NHT, ringkasan hasil uji normalitas dan dapat dilihat pada Tabel 3.

Tabel 3. Ringkasan Uji Normalitas Data Pre-test dan Post-tes

\begin{tabular}{clcccccc}
\hline \multirow{2}{*}{ Kelompok } & Data & \multicolumn{3}{c}{ Kolmogrov-Smirnov } & \multicolumn{3}{c}{ Shapiro-Wilk } \\
& & Statistik & df & Sig. & Statistik & df & Sig. \\
\hline \multirow{2}{*}{ Eks. 1 } & Pre-test & 0,133 & 36 & 0,110 & 0,949 & 36 & 0,100 \\
& Post-test & 0,079 & 36 & 0,200 & 0,981 & 36 & 0,771 \\
Eks. 2 & Pre-test & 0,118 & 36 & 0,200 & 0,963 & 36 & 0,274 \\
& Post-test & 0,101 & 36 & 0,200 & 0,966 & 36 & 0,323 \\
\hline
\end{tabular}

Berdasarkan Tabel 3, data skor pre-test dan post-test siswa baik kelas eksperimen 1 maupun kelas eksperimen 2 adalah berdistribusi normal. Nilai signifikasi pre-test yang diperoleh kelas eksperimen 1 dan kelas eksperimen 2 yang diuji menggunakan Kolmogrov-Smirnov 0,110 dan 0,200 dan nilai signifikasi post-test yang diperoleh kelas eksperimen 1 dan kelas eksperimen 2 secara berturut-turut sebesar 0,200 dan 0,200. Nilai signifikasi pre-test yang diperoleh kelas eksperimen 1 dan kelas eksperimen 2 yang diuji menggunakan statistik Shapiro-Wilk secara berturut-turut sebesar 0,100 dan 0,274 dan nilai signifikasi post-test yang diperoleh kelas eksperimen 1 dan kelas eksperimen 2 berturut-turut sebesar 0,771 dan 0,232 .

Uji homogenitas varians dilakukan dengan menggunakan teknik Levene Test terhadap data nilai pre-test dan post-test kelas eksperimen 1 dan kelas ekperimen 2, ringkasan hasil uji homogenitas varians dapat dilihat pada Tabel 4.

Tabel 4. Ringkasan Hasil Uji Homogenitas Data Keseluruhan

\begin{tabular}{llrrrr}
\hline \multicolumn{1}{c}{ Kriteria } & $\begin{array}{c}\text { Levene } \\
\text { Test }\end{array}$ & Df 1 & Df 2 & Sig \\
\hline Pre-test & Based on Mean & 0,003 & 1 & 70 & 0,957 \\
& Based on Median & 0,000 & 1 & 70 & 0,998 \\
& Based on Median and with adjusted & 0,000 & 1 & 66,300 & 0,998 \\
df & & & & \\
& Based on trimmrd mean & 0,004 & 1 & 70 & 0,951 \\
& Based on Mean & 1,015 & 1 & 70 & 0,317 \\
& Based on Median & 1,011 & 1 & 70 & 0,318 \\
& Based on Median and with adjusted & 1,011 & 1 & 66,336 & 0,318 \\
& df & & & & 0,325 \\
\hline
\end{tabular}

Berdasarkan data Tabel 4, varians antara kelas, baik pada pre-test maupun post-test adalah homogen, ini didasarkan atas nilai signifikasi rata-rata (Based on Mean) yang diperoleh dari hasil pre-test dan post-test lebih besar dari 0,050. Nilai signifikasi rata-rata pada lajur (Based on Mean) yang diperoleh dari hasil pre-test dan post-test berturut-turut sebesar 0,957 dan 0,317.

Uji linieritas data dilakukan dengan menggunakan Test of Linierity. Uji linieritas ini menunjukkan hubungan linier antara pengetahuan awal siswa yang diperoleh dari skor pre-test dengan hasil belajar 
siswa yang diperoleh dari skor post-test pada kelompok TAI dan NHT, ringkasan hasil uji linieritas data dapat dilihat pada Tabel 5 .

Tabel 5. Ringkasan Hasil Uji Linieritas Data

\begin{tabular}{|c|c|c|c|c|c|c|c|c|}
\hline Kelompok & & & & $\begin{array}{l}\text { Sum of } \\
\text { Square }\end{array}$ & $\mathrm{df}$ & $\begin{array}{l}\text { Mean } \\
\text { Square }\end{array}$ & $\mathrm{F}$ & Sig. \\
\hline \multirow{6}{*}{ Eks. 1} & \multirow{6}{*}{$\begin{array}{l}\text { Pretest* } \\
\text { Posttest }\end{array}$} & \multirow{4}{*}{$\begin{array}{l}\text { Between } \\
\text { Group }\end{array}$} & Combined & 716,74 & 12 & 59,72 & 1,6 & 0,148 \\
\hline & & & Linearity & 59,19 & 1 & 59,19 & 1,6 & 0,215 \\
\hline & & & Devination & & & & & \\
\hline & & & $\begin{array}{c}\text { from } \\
\text { Linearity }\end{array}$ & 657,55 & 11 & 59,77 & 1,6 & 0,152 \\
\hline & & \multicolumn{2}{|c|}{ Within Group } & 836,94 & 23 & 36,38 & & \\
\hline & & \multicolumn{2}{|c|}{ Total } & 1553,6 & 35 & & & \\
\hline \multirow{5}{*}{ Eks. 2} & \multirow{5}{*}{$\begin{array}{l}\text { Pretest* }^{*} \\
\text { Posttest }\end{array}$} & \multirow{3}{*}{$\begin{array}{l}\text { Between } \\
\text { Group }\end{array}$} & Combined & 347,55 & 14 & 24,82 & 0,7 & 0,694 \\
\hline & & & $\begin{array}{l}\text { Linearity } \\
\text { Devination }\end{array}$ & 0,048 & 1 & 0,048 & 0,0 & 0,970 \\
\hline & & & $\begin{array}{l}\text { from } \\
\text { Linearity }\end{array}$ & 347,50 & 13 & 26,73 & 0,8 & 0,635 \\
\hline & & \multirow{2}{*}{\multicolumn{2}{|c|}{$\begin{array}{l}\text { Within Group } \\
\text { Total } \\
\end{array}$}} & 682,91 & 21 & 32,52 & & \\
\hline & & & & 1030,4 & 35 & & & \\
\hline
\end{tabular}

Berdasarkan Tabel 5 tentag hasil uji linieritas data pre-test dan post-test kelas eksperimen 1 dan kelas eksperimen 2, menunjukkan bahwa angka signifikasi untuk kelas eksperimen 1 sebesar 0,152 dan angka signifikasi kelas eksperimen 2 sebesar 0,635. Angka signifikasi ini lebih besar dari 0,050. Hal ini menunjukkan bahwa hubungan antara pre-test dan post-test hasil belajar siswa pada masing-masing kelompok maupun secara keseluruhan adalah linier.

Uji homogenitas kemiringan garis regresi (uji interaksi) dilakukan untuk mengetahui ada tidaknya interaksi antara skor pre-test dan skor post-tes pada kelas eksperimen 1 serta skor pre-test dan skor post-test pada kelas eksperimen 2, ringkasan hasil uji homogenitas garis regresi (uji interaksi) dapat dilihat pada Tabel 6 .

Tabel 6. Ringkasan Hasil Uji Homogenitas Kemiringan Garis Regresi

\begin{tabular}{lccccc}
\hline \multicolumn{1}{c}{ Source } & $\begin{array}{c}\text { Type III Sum of } \\
\text { Squares }\end{array}$ & $d f$ & Mean Square & $F$ & Sig. \\
\hline Corected Model & 338,832 & 2 & 169,416 & 4,483 & 0,015 \\
Intercept & 15663,261 & 1 & 15663,261 & 414,470 & 0,000 \\
Pretest Kelas $_{\text {Error }}^{338,832}$ & 2 & 169,416 & 4,483 & 0,015 \\
Total & 2607,582 & 69 & 37,791 & & \\
Corected Total & 438579,750 & 72 & & & \\
\hline
\end{tabular}

Berdasarkan Tabel 6, nilai signifikasi yang diperoleh pada lajur Pretest*Kelas yaitu sebesar 0,015. Angka signifikasi ini menunjukkan kurang dari 0,050. Hal ini mengindikasikan bahwa terdapat interaksi antara skor pre-test dan skor post-test pada kelas eksperimen 1 maupun kelas eksperimen 2. Adanya interaksi ini menyebabkan pre-test tidak cocok digunakan sebagai kovariat. Dengan tidak terpenuhinya uji prasyarat analisis kovarian, maka uji analisis kovarian tidak dapat dilakukan. Dengan demikian uji analisis beralih menggunakan uji t-test dengan rancangan post-test only control group design. Sebelum uji $t$-test dilakuakn, perlu dilaksanakan uji kesetaraan antara kelompok dengan menggunakan skor pre-test.

Uji kesetaraan antar kelompok dilakukan dengan menguji skor pre-test kedua kelompok kelas menggunakan uji Independent-Sample t-test. Uji kesetaraan antar kelompok dilakukan dengan tujuan untuk mengetahui ada atau tidaknya perbedaan pemahaman awal siswa sebelum dilakukan perlakuan. Ringkasan hasil uji kesetaraan kelompok dapat dilihat pada Tabel 7. 
Tabel 7. Hasil Analisis Uji Kesetaraan Kelompok

\begin{tabular}{|c|c|c|c|c|c|c|}
\hline \multicolumn{7}{|c|}{$\begin{array}{c}\text { Independent Sample Test } \\
\text { Levene's Test } \\
\text { for Equality of } \\
\text { Variances }\end{array}$} \\
\hline & & $\mathrm{F}$ & Sig & $\mathrm{T}$ & $\mathrm{df}$ & Sig. (2-tailed) \\
\hline Pre-test & $\begin{array}{l}\text { Equal variances } \\
\text { assusmed } \\
\text { Equal Variances } \\
\text { not Assumed }\end{array}$ & 0,003 & 0,957 & $-0,652$ & 69,439 & 0,517 \\
\hline
\end{tabular}

Berdasarkan data Tabel 7, nilai signifikasi pada lajur pre-test Equal variances assusmed adalah 0,517. Nilai signifikasi yang diperoleh ini lebih besar dari 0,050, sehingga dapat dikatakan bahwa pemahaman awal siswa pada kelas kelas eksperimen 1 dan kelas eksperimen 2 adalah setara.

\section{Uji Hipotesis}

Uji hipotesis dilakukan dengan menggunakan uji analisis Indepentesnt Sample t-test. Pada pengujian hipotesis, hipotesis yang diuji adalah hipotesis nol $\left(\mathrm{H}_{0}\right)$.

$\mathrm{H}_{0} \quad$ : Tidak terdapat perbedaan yang signifikan antara hasil belajar kimia siswa yang dibelajarkan dengan menggunakan model pembelajaran kooperatif tipe team assisted individualizaton (TAI) dengan tipe numbered heads together (NHT)

Ha : Terdapat perbedaan yang signifikan antara hasil belajar kimia siswa yang dibelajarkan dengan menggunakan model pembelajaran kooperatif tipe team assisted individualizaton (TAI) dengan tipe numbered heads together (NHT)

Ringkasan uji analisis Indepentesnt Sample t-test dapat dilihat pada Tabel 9.

Tabel 9. Ringkasan Hasil Uji Independent Sample t-test

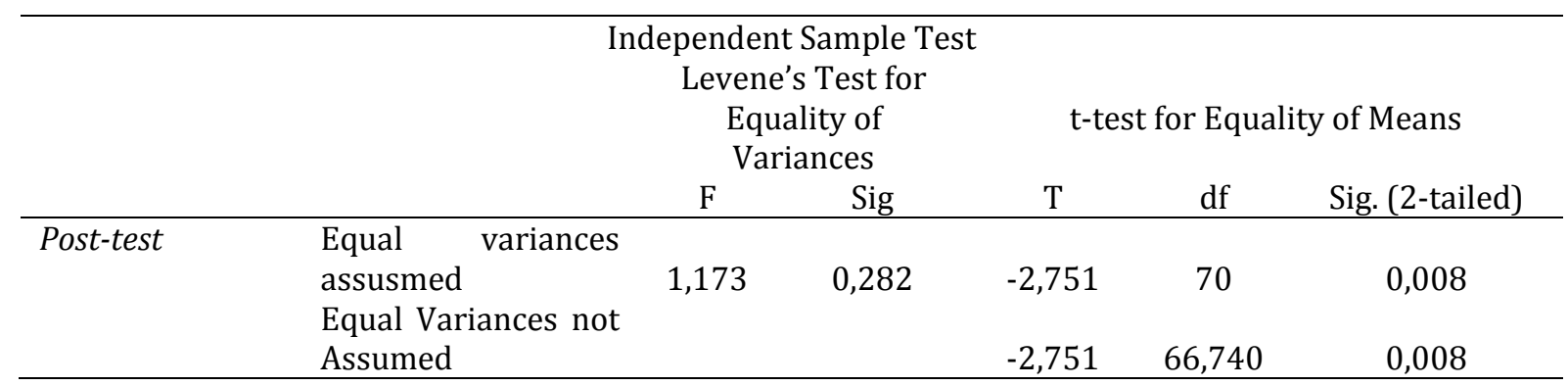

Berdasarkan Tabel 9, menunjukkan angka signifikasi sebesar 0,008. Angka signifikan tersebut lebih kecil dari 0,050. Dengan demikian dapat diambil kesimpulan bahwa $\mathrm{H}_{0}$ ditolak dan $\mathrm{H}_{\mathrm{a}}$ diterima, sehingga dapat ditarik kesimpulan bahwa: "terdapat perbedaan yang signifikan antara hasil belajar kimia siswa yang dibelajarkan dengan menggunakan model pembelajaran kooperatif tipe team assisted individualizaton (TAI) dengan tipe numbered heads together (NHT)"

\section{PEMBAHASAN}

Berdasarkan pengujian hipotesis yang dilakukan dengan menggunakan uji analisis t-test diperoleh angka signifikasi 0,008. Angka signifikasi yang diperoleh kurang dari 0,050 yang mengindikasikan bahwa terdapat perbedaan hasil belajar kimia yang signifikan antara siswa yang dibelajarkan menggunakan model pembelajaran kooperatif tipe TAI dan hasil belajar siswa yang belajar menggunakan model pembelajaran kooperatif tipe NHT. Hasil belajar siswa (post-test) pada siswa kelompok TAI dan kelompok NHT menunjukkan skor rata-rata 75,54 dan 80,02. Skor rata-rata post-test siswa yang dicapai pada kelompok NHT lebih besar dibandingkan dengan rata-rata pada kelompok TAI, hal ini sesuai dengan penelitian yang dilakukan oleh Ruslan (2014) tentang komparasi model pembelajaran kooperatif tipe TAI dan NHT, menyatakan bahwa model pembelajaran kooperatif tipe NHT lebih baik dibandingkan dengan model pembelajaran kooperatif tipe TAI.

Proses pembelajaran kelompok NHT lebih menekankan pada semua anggota kelompok untuk lebih bekerjasama dalam meyelesaikan persoalan dan lebih memahami materi secara keseluruhan, hal ini disebabkan saat proses presentasi di depan kelas hanya satu orang yang nomoronya dipanggil akan 
mewakili semua anggota kelompok, sehingga tugas untuk presentasi tidak hanya dibebankan pada satu orang. Semua anggota kelompok harus siap untuk mewakili kelompokknya. Peserta didik yang pandai mengajari peserta didik yang kurang pandai, hal ini sesuai dengan penelitian yang dilakukan oleh Danti, dkk. (2015) tentang komparasi model pembelajaran kooperatif tipe TAI dan NHT terhadap hasil belajar statistik. Peningkatan hasil belajar dengan menggunakan model pembelajaran kooperatif tipe NHT juga didukung oleh beberapa penelitian, penelitian yang dilakukan oleh Asnawiyah, dkk. (2015) menyatakan bahwa model pembelajaran kooperatif tipe NHT dapat meningkatkan hasil belajar siswa. Malikhan (2014) menyatakan bahwa penerapan model pembelajaran kooperatif tipe NHT dapat meningkatkan hasil belajar pada materi reaksi reduksi oksidasi. Hasil penelitian dari Hartika (2015) yang menyatakan bahwa model pembelajaran kooperatif tipe NHT berbasis VCT dapat meningkatkan keterampilan berkomunikasi dan meningkatkan hasil belajar. Keempat, hasil penelitian dari Putriani (2016) menyatakan bahwa model pembelajaran kooperatif tipe NHT dapat meningkatkan hasil belajar kimia. Kelima, hasil penelitian dari Mahmudah, dkk. (2015) menyatakan bahwa penerapan model pembelajaran kooperatif tipe NHT berbasis multiple representasi dapat meningkatkan hasil belajar siswa. Hal ini juga didukung oleh aktivitas siswa yang diamati selama kegiatan pembelajaran berlangsung.

Skor rata-rata aktivitas siswa yang diperoleh pada kelompok NHT dari ketiga indikator menunjukkan kategori cukup aktif. Indikator mengajukan pertanyaan dalam diskusi kelas tergolong dalam kriteria aktif, hal ini disebabkan karena dalam proses pembelajaran berlangsung siswa aktif bertanya jika kurang paham terhadap materi pelajaran. Pada indikator keaktifan menjawab pertanyaan dan antusiasme dalam mengikuti pembelajaran tergolong dalam kriteria cukup aktif, hanya beberapa siswa yang aktif menjawab pertanyaan yang diberikan oleh guru dan beberapa sisiwa terlihat ragu-ragu. Pada indikator antusiame dalam mengikuti pembelajaran, hanya beberapa siswa terlihat antusias dalam mengikuti pembelajaran hal ini terbukti dari ketekunan dalam mengerjakan tugas yang diberikan, hal ini sesuai dengan hasil penelitian dari Firmansyah, dkk. (2017) menyatakan bahwa penggunaan model pembelajaran kooperatif tipe NHT dapat meningkatkan aktivitas belajar siswa. Hasil penelitian dari Novieza (2014) menyatakan bahwa penggunaan model pembelajran kooperatif tipe NHT dapat meningkatkan aktivitas belajar siswa pada pelajaran ekonomi kelas X MAN X Kota Singkarak.

Berdasarkan respon siswa terhadap model pembelajaran kooperatif tipe NHT, aspek motivasi dan aspek interaksi tergolong ke dalam kriteria sangat positif, sedangkan aspek tanggung jawab dan pengetahuan tergolong dalam aspek positif. Beberapa penelitian yang menunjukkan bahwa model pembelajaran kooperatif tipe NHT dapat memberikan respon yang positif terhadap hasil belajar siswa, yaitu (1) hasil penelitian dari Fatimah, dkk. (2014) menyatakan bahwa penerapan model pembelajaran kooperatif tipe NHT dapat menumbuhkan repon yang positif (setuju) terhadap model pembelajaran yang diterapkan; (2) hasil penelitian yang dilakukan oleh Stefany dan Suliyanah (2012) menyatakan bahwa model pembelajaran kooperatif tipe NHT dapat menimbulkan respon yang positif terhadap hasil belajar siswa pada materi kalor.

Walaupun penerapan model pembelajaran kooperatif tipe NHT memiliki banyak keunggulan, tetapi ditemukan beberapa kendala dalam proses pembelajaran berlangsung. Pada pertemuan pertama kendala yang dijumpai adalah kekurangan waktu dalam melakukan diskusi kelompok. Pada saat pengerjaan tugas kelompok siswa lebih banyak bermain dengan temannya sehingga ada beberapa kelompok yang tidak dapat menyelesaikan permasalahan atau soal yang diberikan. Kekurangan dalam pertemuan pertama diperbaiki dalam pertemuan selanjutnya, dalam pertemuan kedua setiap anggota kelompok diberikan tugas masing-masing untuk menyelesaikan soal yang dikoordinir oleh satu orang (ketua kelompok) sehingga setiap anggota kelompok memiliki tanggung jawab sendiri-sendiri. Setelah semua anggota kelompok menyelesaikan tugas masing-masing, siswa saling bertukar pendapat, berdiskusi, mengklasifikasikan, dan mempersatukan pemikiran serta pendapat masing-masing anggota kelompok. Hal ini dilakukan agar penerapan model pembelajaran kooperatif tipe NHT lebih efektif dalam penerapannya.

Pada kelompok TAI siswa terlebih dahulu belajar individu sebelum belajar kelompok, saat pembelajaran kelompok lebih didominasi oleh siswa yang lebih pintar, sehingga saat presentasi hanya dibebankan oleh siswa yang lebih pandai. Hal ini didukung oleh aktivitas siswa dalam proses pembelajaran. Pada kelompok TAI menunjukkan rata-rata cukup aktif, dari ketiga indikator yaitu indikator mengajukan pertanyaan, menjawab pertanyaan, dan antusiasme dalam kategori cukup aktif, hal ini disebabkan karena terdapat siswa yang bermain-main dalam proses pembelajaran berlangsung sehingga hanya beberapa siswa yang mengajukan pertanyaan, dan menjawab pertanyaan, selain itu hanya beberapa siswa yang tergolong antusis dalam mengikuti proses pembelajaran. Respon siswa pada kelompok yang dibelajarkan dengan menggunakan model pembeloajaran kooperatif tipe TAI menunjukkan respon yang positif pada aspek motivasi, interaksi, tanggung jawab, dan pengetahuan. 
Hasil belajar siswa erat kaitannya dengan aktivitas dan motivasi siswa selama mengikuti pembelajaran. Sukmayasa, dkk. (2013) menyatakan bahwa model pembelajaran kooperatif tipe NHT dengan bantuan senam otak dapat meningkatkan aktivitas dan hasi belajar siswa pada pelajaran matematika. Rofiqoh (2015) menyatakan bahwa model pembelajaran kooperatif tipe NHT disertai media monopoli games terintegrasi pendekatan problem solving pada pembelajaran fisika menimbulkan respon yang positif. Model pembelajaran kooperatif tipe NHT merupakan model pembelajaran yang mampu menciptakan kondisi belajar yang mengajak siswa aktif dalam pembelajaran, hal ini disebabkan karena siswa satu dengan siswa yang lainnya akan saling berinteraksi dalam menyelesaikan tugas yang diberikan. Selain itu model pembelajaran ini juga membuat siswa untuk lebih memahami materi pelajaran, karena setiap siswa harus siap untuk mempresentasikan materi yang dibahas dalam kelompoknya sebagai perwakilan kelompok. Interaksi dan motivasi siswa juga meningkat dengan digunakan model pembelajaran kooperatif tipe NHT.

Pemaparan di atas menunjukkan bahwa ada hubungan yang sejalan antara hasil belajar siswa, aktivitas siswa, dan respon siswa pada model pembelajaran yang diterapkan. Terlihat bahwa hasil belajar siswa yang dibelajarkan dengan model pembelajaran kooperatif tipe NHT lebih tinggi dari pada siswa yang dibelajarkan dengan menggunakan model pembelajaran kooperatif tipe TAI. Bagi guru di sekolah hasil penelitian ini menjadi bahan pertimbangan untuk memilih tipe NHT dalam meningkatkan hasil belajar siswa terutama pada materi struktur atom.

\section{Simpulan dan saran}

Rata-rata hasil belajar siswa yang dibelajarkan dengan menggunakan model pembelajaran kooperatif tipe NHT $(80,02)$ lebih tinggi dibandingkan dengan siswa yang dibelajarkan dengan menggunakan model pembelajaran kooperatif tipe TAI $(75,54)$. Aktivitas dan respon siswa dengan menggunakan model pembelajaran kooperatif tipe NHT lebih baik dibandingkan dengan model pembelajaran kooperatif tipe TAI.

Berdasarkan penelitian yang telah dilakukan, dapat diajukan beberapa saran dalam perbaikan dan peningkatan kualitas pembelajaran kimia, yaitu sebagai berikut. 1. Diharapkan guru kimia dapat mengimplementasikan model pembelajaran kooperatif tipe NHT dalam pelajaran khususnya pada materi struktur atom karena model pembelajaran kooperatif tipe NHT telah terbukti memiliki keunggulan dalam meningkatkan hasil belajar kimia pada materi struktur atom. 2 Pada saat proses pembelajaran berlangsung setiap anggota kelompok sebaiknya membagi-bagi permasalahan yang ditemukan, sehingga dapat menghemat waktu, 3. Perlu adanya penelitian lebih lanjut untuk mengkomparasikan model pembeljaran kooperatif tipe NHT dengan model pembeljaran lainnya, serta mengimplementasikan model pembelajaran koopetarit tipe NHT terhadap materi pelajaran lainnya yang bersifat abstrak

\section{Daftar Rujukan}

Asnawiyah, R., Luk, E., Leica, D. F. 2015. "Penerapan Model Pembelajaran Koope NHT terhadap Hasil Belajar Matematika Kelas X MIA SMA Negeri 1 Bangun Purba”. E-Journal UPP Pasir Pengarai, Vol 1, No 1 (hlm. 5-11).

Chang, R. 2005. Kimia Dasar: Konsep-Konsep Inti Jilid I (Terjemahan). Jakarta: Erlangga.

Danti, D. P. N., Supriayitno, I., Prihaswati, M. 2015. "Perbandingan Pembelajaran NHT dengan TAI Berpendekatan Kontruktivisme Terhadap Prestasi Belajar". Jurnal Kependidikan Matematika, Vol 2, No 1 (hlm. 15-21).

Fatimah, S., Jalmo, T., Marpawng, R.R.T. 2014. "Pengaruh Penerapan Model Pembelajaran Kooperatif Tipe NHT terhadap Keterampilan Berpikir Siswa". Jurnal Pendidikan, Vol 2, No 1 (hlm. 49-60).

Firmansyah. Y., Mahardika, I. K., Gani, A. A. 2017. "Pengaruh Model Pembelajaran Kooperatif Tipe NHT Berbantuan Media Simulasi PHET terhadap Aktivitas dan Hasil Belajar Siswa SMA di Jember". Jurnal Pembelajaran Fisika, Vol 6, No 1 (hlm. 97-102).

Hartika, H. 2015. "Penerapan Model Pembelajaran Kooperatif Tipe NHT Berbasis VCT terhadap Hasil Belajar, Aktivitas, dan Keterampilan Berkomunikasi”. Jurnal Pendidikan, Vol 21, No 1 (hlm. 151).

Johnstone, A. H. 2006. Chemical Education Research in Glasgow in Perspective. The Journal Of Chemistry Education Research And Practice, Vol 7, No 2, (hlm. 49-63).

Mahmudah, Suyanto, Widodo, W. 2015. “Penerapan Model Pembelajaran Kooperatif Tipe NHT Berbasis Multiple Representasi terhadap Hasil Belajar Siswa SMA N Pekanbaru” Jurnal Pendidikan, Vol 1, No 1 (hlm. 1-9).

Malikan, M. 2014. "Penerapan Model Pembelajaran Kooperatif Tipe NHT terhadap Hasil Belajar Siswa pada Pembelajaran Kimia”. E-Journal Pembelajaran Kimia, Vol 17, No 5 (hlm. 101).

Mulyana, H. 2016. "Penerapan model pembelajaran kooperatif Tipe NHT untuk Meningkatkan Hasil Belajar". Jurnal Pendidikan, Vol 3, No 2 (hlm.75-81). 
Novieza, M. 2014. "Pengaruh Model Pembelajaran Kooperatif Tipe NHT terhadap Motivasi dan Hasil Belajar Ekonomi pada Siswa Kelas X MAN X Kota Singkarak". Jurnal Pendidikan, Vol 1, No 1 (hlm. 1 9).

Putriani, D. D. S. 2016. "Penerapan Model Pembelajaran Kooperatif Tipe NHT terhadap Hasil Belajar Kimia di SMA N Pekanbaru” Jurnal Pendidikan, Vol 1, No 1 (hlm. 1-9).

Rofiqoh, F. 2015. "Pengaruh Model Pembelajaran Kooperatif Tipe NHT Disertai Media Monopoli Games Terintegrasi Pendekatan Problem Solving pada Pembelajaran Fisika Di SMA" Jurnal Pembelajaran Fisika, Vol 4, No 3 (hlm. 35).

Ruslan, J. M. 2014. “Komparasi Model Pembelajaran Kooperatif Tipe TAI Dan NHT terhadap Hasil Belajar Kimia Siswa Kelas XI MAN Pekanbaru". Jurnal Pendidikan MIPA, Vol 34, No 7 (hlm. 60).

Rusman. 2012. Model-Model Pembelajaran Mengembangkan Profesionalisme Guru. Jakarta: PT Rajagrafindo Persada.

Sarwendah, R.H, Martini, K. S., Utami B. 2013. "Studi Komparasi Pembelajaran Kimia Menggunakan Model Pembelajaran Kooperatif Metode TGT dan TAI pada Materi Pokok Sistem Koloid Kelas XI IPA SMA Negeri 2 Sukoharjo Tahun Pelajaran 2011/2012". Jurnal Pendidikan Kimia, Vol 2, No 1 (hlm. 4247).

Slavin, R. E. 2008. Cooperative Learning Teori Risert dan Praktik. Terjemahan Lita. Bandung: Nusa Media.

Solahudin, A. 2002. "Analisis Pemahaman Konsep Siswa SMA Kelas X pada Materi Struktur Atom Melalui Pendekatan Saintifik". Jurnal Pendidikan Nasional dan Kebudayaan, Vol 2, No 1 (hlm. 36-47).

Stefany \& Suliyanah. 2012. "Pengaruh Model Pembelajaran Kooperatif Tipe NHT dengan Metode Snow Ball Throwing terhadap Hasil Belajar Siswa pada Materi Kalor di Kelas X SMA Negeri 2 Bangkalan". Jurnal Pendidikan, Vol 3, No 5 (hlm. 35-42).

Sukmayasa, I. M. H., Budi, M. 2013. “ Pengaruh Model Pembelajaran Kooperatif Tipe NHT Berbantuan Senam Otak terhadap Keaktifan dan Prestasi Belajar Matematika" Jurnal Pendidikan, Vol 3, No 4 (hlm. 35-47).

Sutirman. 2013. Media dan Model-Model Pembelajaran Inofatif. Yogyakarta: Graha Ilmu) 